Atatirk Üniversitesi Veteriner Bilimleri Dergisi

\title{
Isolation and Identification of Campylobacter jejuni and Campylobacter coli From Various Animal Source Foods by Conventional Methods and PCR*
}

\section{Serap KILIC ALTUN ${ }^{1}$, Ekrem KIREÇCi ${ }^{2 \varpi}$, Ömer Faruk KUCUKKALEM ${ }^{1}$, Şenay SEYITOGLU ${ }^{1}$}

1. Erzurum Veterinary Control Institute, Erzurum, Turkey.

2. University of Sutcu imam, Faculty of Medicine, Department of Microbiology, Kahramanmaras, Turkey.

\begin{abstract}
In this study, 300 samples consisted of chicken meats, ground beef, and gallbladder of cattle and sheep were collected from various markets, butchers and abattoirs in the Eastern Anatolia region in Turkey. The samples were evaluated for the presence of Campylobacter jejuni and Campylobacter coli. Campylobacter spp. was isolated from 16 (5.3\%) of the samples by conventional methods. The isolates were identified by biochemical analyses and the polymerase chain reaction technique, which revealed that 12 (75\%) of samples were Campylobacter jejuni while 4 (25\%) of them were Campylobacter coli. As a result, it was considered that Campylobacter species, an important category of microorganisms causing acute bacterial gastroenteritis in humans, are commonly transmitted through foods in animal origin.
\end{abstract}

Key words: Campylobacter coli, Campylobacter jejuni, Cattle meat, Chicken meat, Sheep meat.

\section{Farklı Hayvansal Gıdalarda Campylobacter jejuni ve Campylobacter coli'nin Konvansiyonel Kültürel Metod ve PCR ile İzolasyonu ve İdentifikasyonu}

Özet: Bu araştırmada Kuzeydoğu Anadolu Bölgesinde bulunan farklı market, kasap ve kesimhanelerden alınan tavuk eti, koyun eti (kıyma), sığır eti (kıyma) ve safra kesesi olmak üzere toplam 300 örnek incelendi. Tüm örnekler Campylobacter jejuni ve Campylobacter coli yönünden incelendi. Konvansiyonel metodlar ile örneklerin 16'sında (\%5.3) Campylobacter spp. pozitif bulundu. İzolatlar biyokimyasal analizler ve PCR tekniği ile tanımlandı. İzolatların 12'sinde (\%75) Campylobacter jejuni ve 4'ünde (\%25) Campylobacter coli identifiye edildi. Sonuç olarak, Campylobacter türlerinin, genellikle insanlara hayvansal gıdalarla bulaşan akut bakteriyel gastroenteritise sebep olan önemli zoonozlardan olduğu düşünülmektedir.

Anahtar kelimeler: Campylobacter coli, Campylobacter jejuni, Koyun eti, Sığır eti, Tavuk eti. 


\section{INTRODUCTION}

C urrently, although numerous microorganism groups lead to enteritis and diarrhoea in humans, Campylobacter coli (C. coli) and Campylobacter jejuni (C. jejuni) species of the genus Campylobacter are commonly isolated in diarrhoea patients (Friedman et al., 2000). These species also cause abortion and serious economic losses in farm animals (Ertaş et al., 2002). These pathogenic bacteria have a zoonotic character, display a commensalist existence in the intestinal lumen of different animals, and induce various intestinal and extra-intestinal diseases in humans via contaminated food and water (Örmeci, 2007). Campylobacter species generally grow at $37{ }^{\circ} \mathrm{C}$, while $C$. jejuni and $C$. coli species are thermophilic and grow at $42{ }^{\circ} \mathrm{C}$. Since these two species share many identical phenotypic characters, some difficulties are encountered in their microbiological differentiation. In numerous studies, both DNAbased molecular methods, such as polymerase chain reaction ( $P C R$ ), in addition to conventional methods were used to differentiate the species. Determination of new target genes specific to the Campylobacter species has facilitated the identification of these bacteria (Oyofo et al., 1992; Açık, 2006). In this study, we aimed to identify $C$. jejuni and $C$. coli in samples obtained from animal sources by using conventional methods and PCR technique.

\section{MATERIALS and METHODS}

\section{Sample Collection}

In this study, 300 samples were collected. The samples consisted of chicken meats (100), ground beef (50) of cattle and sheep (50), gallbladder of cattle (50) and sheep (50). The samples were collected randomly at butchery, abattoirs, and markets in the Eastern Anatolia Region, Turkey. All collected samples were stored in clean bags and freighted to laboratory for preparation. The samples were carried to the laboratory within $1 \mathrm{~h}$ and analysed in the same day.

\section{Culture and Isolation}

Following the acquisition of chicken meat, ground beef, and gallbladder bile samples under aseptic conditions, pre-enrichment procedure was carried out in campylobacter selective broth (OXOID CM0067B) at $42{ }^{\circ} \mathrm{C}$ for 48 hours in a microaerophilic environment. After the enrichment, the samples were subcultured into campylobacter selective agar (OXOID CM0739B), and the bacterial growths on plates were then evaluated for their colony formation and microscopic characteristics (Oyofo et al., 1992; Ertaş et al., 2002).

\section{Biochemical Tests}

The pre-diagnosis was achieved on colony suspected of Campylobacter spp., by using conventional methods and a Vitek II COMPAQ system (Biomerieux). Gram staining, motility, catalase, nitrate reduction, $\mathrm{H}_{2} \mathrm{~S}$, hippurate hydrolysis, urea, arginine arylamidase, gammaglutamyl transferase, and other biochemical tests (Leucyne Arylamidase, Ornithine decarboxylase etc.) were applied for this purpose.

\section{Genotypic Confirmation of Isolates}

The DNA extraction from the isolates was performed using a commercial extraction kit (Wizard Genomic DNA Purification Kit, Promega) according to the instructions of the manufacturer. The DNA pellets were dissolved in $50 \mu$ sterile distilled water and stored at $-20{ }^{\circ} \mathrm{C}$ until the analysis. During the PCR, primers specific to the ceuE gene and capable of amplifying a region of $100 \mathrm{bp}$ length in C. jejuni and $130 \mathrm{bp}$ length in C. coli, were used (Aydın et al., 2005).

$$
\text { While CC-F1 Forward (5'- }
$$

CATATTGTAAAACCAAAGCTTATCG-3') and CC-R1 Reverse (5'-AGTCCAGCAATGTGTGCAATG-3') were used for $C$. coli, Cj-F1 Forward (5'TGCTAGTGAgGTtGCAAAAGAATT-3') and Cj-R1 Reverse (5'-TCATTTCGCAAAAAA ATC CAA A-3') 
primers (Tibmol Biol, Germany) were employed for C. jejuni. The reaction mixture consisted of $3.5 \mathrm{mM}$ $\mathrm{MgCl}_{2}, 50 \mathrm{mM} \mathrm{KCl}, 10 \mathrm{mM}$ Tris- $\mathrm{HCl}, 0.2 \mathrm{mM}$ dNTP, $0.5 \mathrm{U}$ Taq DNA polymerase enzymes (Fermentas, Lithuania), and $1 \mu \mathrm{M}$ from each primer in the final concentration of $25 \mu \mathrm{l}$. A $2.5 \mu \mathrm{l}$ target DNA was added into the reaction mixture $(22.5 \mu \mathrm{l})$ to achieve a total volume of $25 \mu \mathrm{l}$. The reaction was carried out in a thermal cycler (Thermo Hybaid, UK) at $95{ }^{\circ} \mathrm{C}$ for 10 minutes in order to reach 40 cycles, at $95{ }^{\circ} \mathrm{C}$ for $20 \mathrm{sec}$, and at $60{ }^{\circ} \mathrm{C}$ for $1 \mathrm{~min}$ (Lagier et al., 2004). Following the amplification, PCR products were run on agarose gel of $2 \%$ at electrophoresis. After that, gel was stained with ethidium bromide and visualized under an ultraviolet (UV) transilluminator.

\section{Reference Strains}

Campylobacter jejuni (ATCC33291) and Campylobacter coli (ATCC 33559) were used as reference strains for DNA extraction and PCR procedures.

\section{RESULTS}

C. jejuni was isolated and identified in 12 (4\%) out of 300 samples examined, whereas $C$. coli was isolated and identified in 4 (1.3\%) of samples. While
C. coli was isolated and identified in 2 chicken meat samples (2\%) and 2 ground mutton (4\%), C. jejuni was isolated and identified from 2 chicken meat samples (2\%), 9 ground mutton (18\%) and only 1 sheep gallbladder (2\%). No Campylobacter spp. was isolated from the cattle ground meat and gallbladder samples collected (Table 1). The genomic DNAs extracted from those isolates were subjected to PCR using Cc-F1/R1 and Cj-F1/R1 primer pairs. Positive bands were found for $C$. jejuni (100 bp) and $C$.coli (130 bp) in $2 \%$ agarose gel (Figures 1 and 2).

Table 1. The distribution of $C$. coli and $C$. jejuni isolates in samples collected.

Tablo 1. Örneklerden izole edilen $C$. coli and $C$. jejuni' nin dağılımı.

\begin{tabular}{lcc}
\hline Animal sources, (n) & C. coli & C. jejuni \\
$\mathbf{n}(\%)$ & $\mathbf{n}(\%)$ \\
\hline Chicken meat, (100) & $2(2)$ & $2(2)$ \\
\hline Cattle gallbladder, (50) & 0 & 0 \\
\hline Cattle ground beef, (50) & 0 & 0 \\
\hline Sheep gallbladder, (50) & 0 & $1(2)$ \\
\hline Sheep ground beef, (50) & $2(4)$ & $9(18)$
\end{tabular}

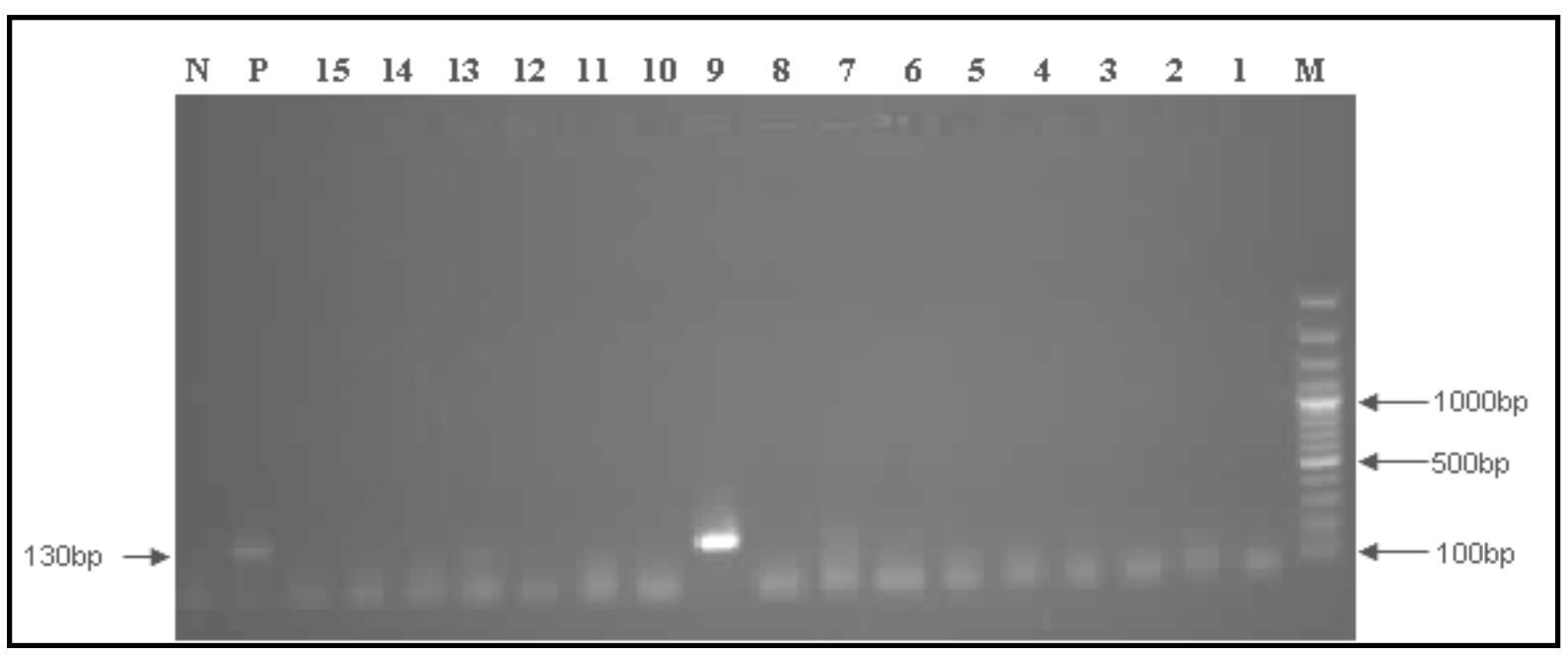

Figure 1. PCR products of Campylobacter coli isolate on agarose gel (2\%) stained with ethidium bromide. M: Marker, 9: Isolate, P: Positive control, N: negative control (distilled water).

Şekil 1. Ethidium bromid ile boyanan $\% 2^{\prime}$ lik agaroz jeldeki Campylobacter coli izolatlarına ait PCR ürünleri M: Marker, 9: İzolat, P: Positif kontrol, N: Negatif kontrol (distile su). 


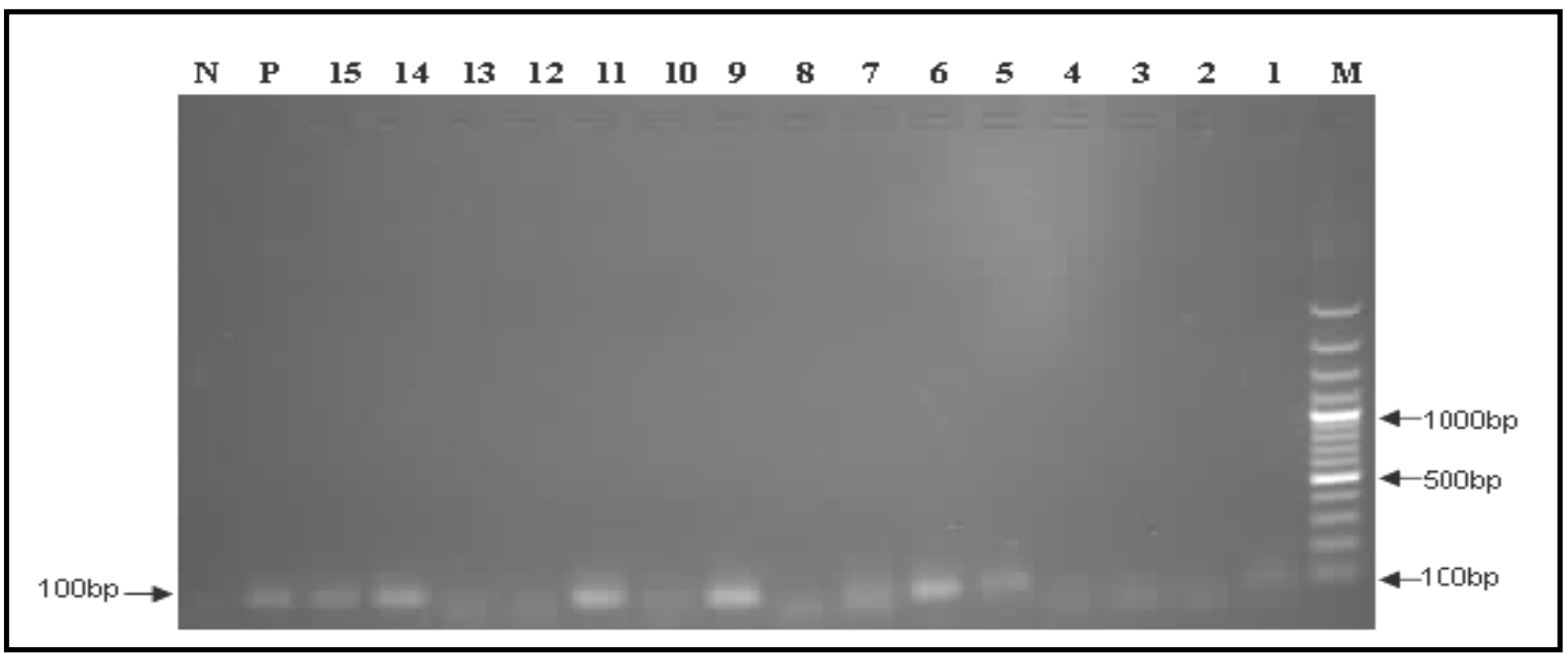

Figure 2. PCR products of Campylobacter jejuni isolate on agarose gel (2\%) stained with ethidium bromide. M: Marker, 1-15: Isolate, P: Positive control, N: negative control (distilled water).

Şekil 2. Ethidium bromid ile boyanan \%2'lik agaroz jeldeki Campylobacter jejuni izolatlarına ait PCR ürünleri M: Marker, 1-15: İzolat, P: Positif kontrol, N: Negatif kontrol (distile su).

\section{DISCUSSION and CONCLUSION}

The C. jejuni, C. coli, C. lari, and C. upsaliensis species of Campylobacter genus are thermophilic bacteria that can grow at $42{ }^{\circ} \mathrm{C}$. Among these, $C$. jejuni and $C$. coli are particularly recognized as the two of the most important food-borne zoonotic pathogens for both human and animal health. In humans, acute bacterial gastroenteritis is associated with C. jejuni in $90-95 \%$ and C. coli in 5-10\% of reported cases (Friedman et al., 2000, Vandamme, 2000). Recently, the prevalence of Campylobacterrelated food infections has been noted as surpassing the prevalence of Salmonella-related infections; thus, the former is predicted to become one of the most frequently isolated food-borne pathogens (Açık, 2006). Etiologic diagnosis has a crucial role to combat with the infections. Although classical (conventional) methods are successful up to the isolation stage, they may lead to inaccurate results in differentiating C. coli and C. jejuni (Açık, 2006). The reliability and validity of these methods are suspicious since numerous authors have achieved different results from the same isolates, and there is not yet standardization for identification using biochemical tests (On, 1996). Therefore, investigators generally recommend molecular techniques using genomic DNA, such as PCR, for a definitive diagnosis and distinction between the species (Sails et al., 1998; Oyofo et al., 1992; Comi et al., 1995). In this study, the identification after isolation was performed using the automatized Vitek II COMPAQ system (based on a system similar to that used in classical biochemical tests), followed by confirmation by PCR.

Various studies have employed the enrichment method to isolate pathogens from samples studied for the presence of Campylobacter spp. (Mehlman and Romero, 1982; Baylis et al., 2000). In the present study, the inoculation and culture technique was used after enrichment in order to improve the isolation rate. Proper collection and transportation of microbiologic samples is critical with regard to accurate diagnosis and isolation because Campylobacter spp. is influenced adversely or favourably by transportation factors such as delivery time (duration from the sample collection to submission to the laboratory). Even if the transportation is fully complied with the cold chain and sterility rules, the isolation rate is reduced in samples that are not examined shortly after 
collection (Gülmez, 1999). Açık (2006) observed a reduced isolation rate when samples collected from the intestinal contents of animals were transported to the laboratory within approximately 12 hours. In the present study, the delivery times of the gallbladder bile samples collected from the abattoir (6-8 hours) were longer than that of meat samples collected from markets (1-2 hours). Trials involving the isolation of Campylobacter species from cattle have produced variable (1-90\%) results in both Turkey and abroad (Rosef et al., 1983, Diker, 1987; Stanley et al., 1998). In one study, the isolation rate of Campylobacter spp. from 1.154 rectal swaps and liver samples collected in the Eastern region of Turkey was 26.1\% (Açık, 2006). In our study, no thermophilic Campylobacter species was isolated from the cattle ground meat and bile samples, whereas the samples collected from sheep demonstrated an isolation rate of $12 \%$. As foodborne pathogens, these species generally cause infections by contaminating poultry meat (Stern and Meinersmann, 1989; Gülmez, 1999). Studies in our country and across the world have shown high isolation rates of $C$. coli and $C$. jejuni in samples of poultry meat (Berry et al., 1988; Gülmez, 1999; Deckert et al., 2010).

By using genotyping techniques in Campylobacter infections, definitive diagnoses, differentiation between species, and various epidemiologic characteristics, such as infection source and routes of transmission, can be determined. Thus, data on isolates can be accurately assessed to develop not only the protection from infections but also new control strategies.

In conclusion, in this study, we were able to isolate and identify Campylobacter spp., particularly in samples obtained from chicken meat and sheep ground beef. Therefore, we believe that the role of animal sources should not be overlooked with regard to public health, and animal products and consumer markets should be frequently inspected to minimize the risk of infection.

\section{REFERENCES}

Açık MN., 2006. Sığır ve koyun orijinli Campylobacter jejuni ve Campylobacter coli'nin moleküler tiplendirilmesi. Fırat Üniversitesi, Sağlık Bilimleri Enstitüsü, Elazığ, Türkiye.

Aydın F., Gümüşsoy KS., İça T., Sümerkan B., Eşel D., Akan M., Özdemir A., 2005. The prevalence of Campylobacter jejuni in various sources in Kayseri, Turkey, and molecular analysis of isolated strains by PCR-RFLP. Turkish J. Vet. Anim. Sci., 31, 13-19.

Bae W., Kaya KN., Hancock DD., Call DR., Park YH., Besser TE., 2005. Prevalence and antimicrobial resistance of thermophilic Campylobacter spp. from cattle farms in Washington State. App. Environ. Microbiol., 71, 169-174.

Baylis CL., Macphee S., Martin KW., Humphrey TJ., Betts RP., 2000. Comparison of three enrichment media for the isolation of Campylobacter spp. from foods. J. App. Microbiol., 89, 884-891.

Berry JT., Hungdahi MB., Doyle MP., 1988. Colonisation of gastrointestinal tract of chicks by C.jejuni. App. Environ. Microbiol., 54, 10, 2365-2370.

Brown PE., Christensen OF., Clough HE., Diggle PJ., Hart CA., Hazel S., Kemp R., Leatherbarrow AJ., Moore A., Sutherst J., Turner J., Williams NJ., Wright EJ., French NP., 2004. Frequency and spatial distribution of environmental Campylobacter spp. App. Environ. Microbiol., 70, 6501-6511.

Comi G., Ferroni P., Cocolin L., Cantoni C., Manzano M., 1995. Detection and identification of Campylobacter coli and Campylobacter jejuni by two-step polymerase chain reaction. Mol. Biotech., 3, 266-268.

Deckert A., Valdivieso-Garcia A., Reid-Smith R., Tamblyn S., Seliske P., Irwin R., Dewey C., Boerlin P., McEwen SA., 2010. Prevalence and 
antimicrobial resistance in Campylobacter spp. isolated from retail chicken in two health units in Ontario. J. Food. Protec., 73, 1317-1324.

Diker KS., 1987. Campylobacter türlerinin çeşitli hayvanlardan izolasyonu ve zoonotik yönlerinin değerlendirilmesi. Mikrobiol. Bült., 21, 268273.

Ertaş HB., Çetinkaya B., Muz A., Öngör H., 2002. Tavuk orijinli Campylobacter coli ve Campylobacter jejuni'nin polimeraz zincir reaksiyonu (PCR) ile identifikasyonu. Turkish J. Vet. Animal Sci., 26, 1447-1452.

Friedman CR., Neimann J., Wegner HC., Tauxe RV., 2000. Epidemiology of Campylobacter jejuni infections in the United States and other industrialized nations. In "Campylobacter", Ed., I, Nachamkin, MJ Blaser, 2th ed., 121-138, American Society for Microbiology, Washington DC.

Gülmez M., 1999. Campylobacter jejuni izolasyonunda bazı kültürel tekniklerin karşılaştırılması ve tavuk etlerinde termofilik Campylobacterlerin araştırılması. Kafkas Üniversitesi, Sağlık Bilimleri Enstitüsü, Kars, Türkiye.

Harvey RB., Droleskey RE., Sheffield CL., Edrington TS., Callaway TR., Anderson RC., Drinnon DL., Ziprin RL., Scott HM., Nisbet DJ., 2004. Campylobacter prevalence in lactating dairy cows in the United States. J. Food Protec., 67, 1476-1479.

Lagier MJ., Joseph LA., Passaretti TV., Musser KA., Cirino NM., 2004. A real time multiplexed PCR assay for rapid detection and differention of Campylobacter jejuni and Campylobacter coli. Mol. Cell. Probes, 18, 275-282.

MehIman IJ., Romero A., 1982. Improved growth medium for Campylobacter species. App. Environ. Microbiol., 43, 615-618.

On SLW., 1996. Identification methods for
Campylobacters, Helicobacters, and related organisms. J. Clin. Microbiol., 9, 405-422.

Oyofo BA., Thornton SA., Burr DH., Trust TJ., Pavlovskis OR., Guerry P., 1992. Specific detection of Campylobacter jejuni and Campylobacter coli by using polymerase chain reaction. J. Clin. Microbiol., 30, 2613-2619.

Örmeci E., 2007. Occurrence of thermophilic Campylobacter spp. in raw milk. Ankara Üniversitesi, Sağlık Bilimleri Enstitüsü, Ankara, Türkiye.

Rosef D., Gondroson B., Kapperud G., Underdal B., 1983. Isolation and characterization of Campylobacter jejuni and Campylobacter coli from domestic and wild mammals in Norway. App. Environ. Microbiol., 46, 855-859.

Sails AD., Bolton FJ., Fox, AJ., Wareng, DRA., Greenway DLA., 1998. A reverse transcriptase polymerase chain reaction assay for the detection of thermophilic Campylobacter spp. Mol. Cell. Prob., 12, 317-322.

Stanley KN., Wallace JS., Currie JE., Diggle PJ., Jones K., 1998. The seasonal variation of thermophilic Campylobacters in beef cattle, dairy cattle and calves. J. App. Microbiol., 85, 472-480.

Stern NJ., Meinersmann RJ., 1989. Potentials for colonization control of C.jejuni in chicken. J. Food Protec., 52, 427-430.

Vandamme P., 2000. Taxonomy of the Family Campylobacteriaceae In: "Campylobacter", Ed., I Nachamkin ve MJ Blaser, 3-27, ASM Press, Washington DC. 